Animal Health Research Institute, Beni-Suef.

\title{
RELATION BETWEEN BOVINE FASCIOLIASIS AND BACTERIAL LIVER INFECTIONS AS WELL AS OTHER INTERNAL PARASITIC INFESTAIONS IN COWS AND BUFFALOES IN BENI-SUEF GOVERNORATE
}

(With 7 Tables and One Figure)

\author{
By \\ M.A. ABDEL-GAWAD and SAMIA I. AFIFI \\ (Received at 18/9/2008)
}

\begin{abstract}
العلاقة بين الاصابة بالفاشيولا واصابات الكبد البكتيرية وكذلك الاصابة

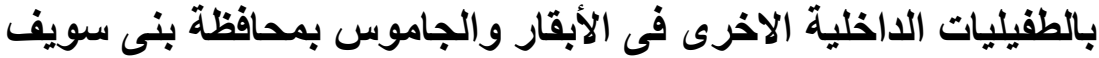
محد أحد عبل الجو/د ، سامبية إبراهيم عفيفى
\end{abstract}

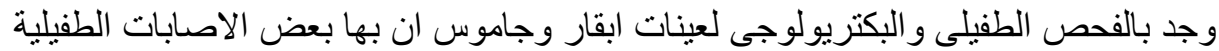

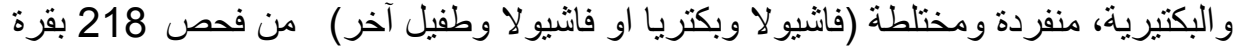

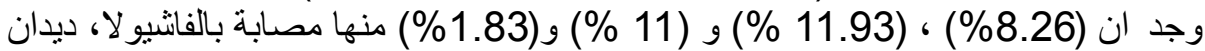

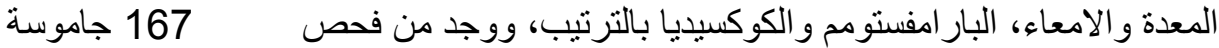

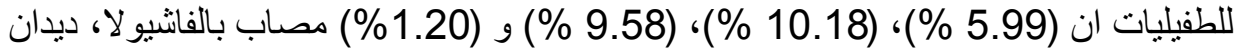

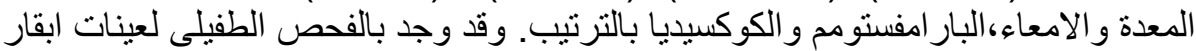

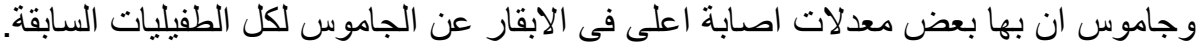

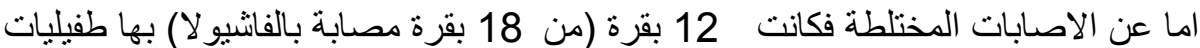

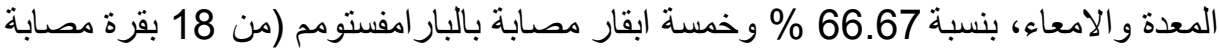

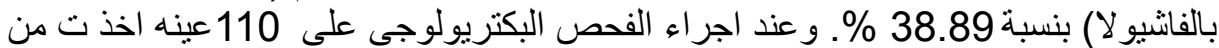

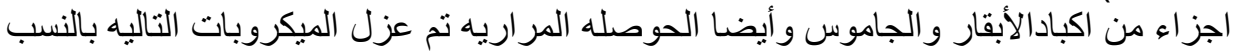

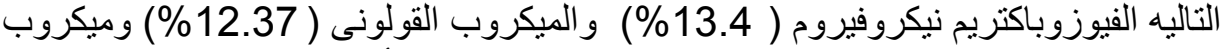

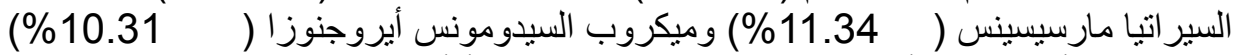

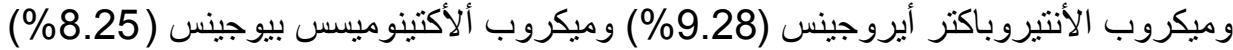

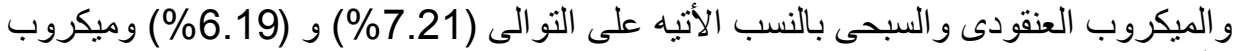

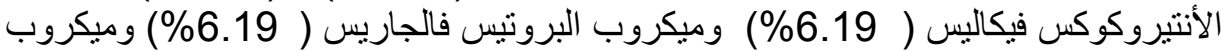

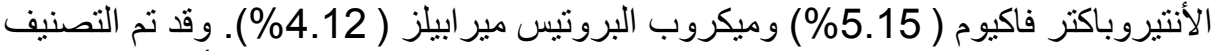

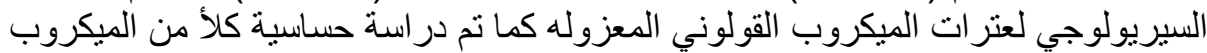

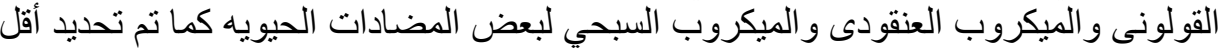
نسبه تركيز لبعض اضافات الأغذيه الدو ائيه

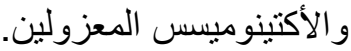

\section{SUMMARY}


Parasitological examination of faeces, gall bladders and livers as well bacteriological examination of gall bladders and livers of cows and buffaloes, revealed the presence of some parasitic and bacterial infections either single or mixed infections (Fasciola with bacteria or with other parasites in one animal). Faecal examination of 218 cows, indicated that $8.26 \%, 11.93 \%, 11 \%$ and $1.83 \%$ cases were infested with Fasciola, Gastro Intestinal Parasites (G.I.P.), Paramphistomum and Coccidia respectively. Also from 167 buffaloes faecal samples 5.99\%, 10.18\%, 9.58\% and 1.20\% were infested with Fasciola, Gastro Intestinal Parasites, Paramphistomum and Coccidia respectively. There were higher rates of infestations with all mentioned parasites in cows than buffaloes. As for mixed infections, 12 from 18 fasciolised cows had faecal-borne parasites (66.67\%), 5 of which were infested with Gastro Intestinal Parasites (27.78\%) and the other 7 cows had paramphistomiasis (38.89\%). Regarding buffaloes 3 from 10 (30\%) had Fasciola and Gastro Intestinal Parasites beside 2 from 10 (20\%) had Fasciola and Paramphistomum. Bacteriological examination of 110 samples of gall bladders and inflamed livers of cows and buffaloes terminated 88 positive samples, 49 of them were mixed with liver fluke infestations and 39 were pure bacterial infection. Different species of bacteria were detected in the examined samples at different rates as follow: Fusobacterium necrophorum (13.40\%), E. coli $(12.37 \%$,$) ,$ Serratia marcescens (11.34\%), Pseudomonous aeruginosa (10.31\%), Enterobacter aerogenes (9.28\%) Actinomyces pyogenes (8.25\%) Staphylococcus aureus (7.21\%), Streptococcus uberis (6.19\%), Enterococcus faecalis (6.19\%), Proteus vulgaris (6.19\%), Enterococcus faecium (5.15\%) and Proteus mirabilis (4.12\%). Serological identification of the isolated $E$. coli determined that 4 strains were O111, 4were O29, 3 were O26 and one strain was O164. Antimicrobial susceptibility of the isolated strains of E. coli, S. aureus and Strept. uberis recovered from the infected livers to different chemotherapeutic agents was discussed and the minimum inhibitory concentrations (MIC) for the isolates of $F$. necrophorum and $A$. pyogenes to some antimicrobial food additives were determined.

Key words: Fascioliasis, bacterial liver infections, internal parasites, cows, buffaloes

\section{INTRODUCTION}


The distribution of several pathogenic helminthes infections coincides geographically with many devastating microbial diseases, including enteric bacterial infections. Many authors dissected the mechanisms by which helminthes modulate the host's response to enteric bacteria and bacteria-mediated intestinal inflammation, Khan et al. (2002), Weng et al. (2007), Silvia et al. (2007). Ogunrinade and Adegoke (1982) in Nigeria mentioned that Trypanosoma spp., Babesia, Paramphistomum and Schistosoma were the most commonly found parasites associated with fascioliasis. The association between pyogenic abscesses caused by Staphylococcus aureus and worm infection has been described by Lambertucci et al. (1990 and 2001), Pinilla et al. (2001). Lambertucci et al. (1998) and Rayes et al. (2000) also found an association between tropical pyomyositis and infection by Toxocara canis.

On the other hand, liver infection with bacteria in cows and buffaloes is a major economic liability to producer, packers and consumers of beef, the liver may be infected with bacteria, liver fluke or both. Bacterial infection of liver occurs at all ages and in all animals, but it has more economic importance in feedlot animals. The aggressive grain feeding programs in feedlot animals may progress acidosis and rumenitis which leading to entrance of pyogenic cocci and other microorganisms to the liver through different routes (Nagaraja and Chengappa 1998). These microorganisms coalesce together to begin liver abscess process that varies in thickness and range in size from a minute pinpoint to over $15 \mathrm{~cm}$ in diameter and affected from 12 to $32 \%$ in most feedlots (Brink et al., 1990). Moreover liver bacterial infection may ascend the billiary passage beside liver fluke may cause liver abscess and bilateral suppurative nephritis (Braun et al., 2004).

The aim of this work was to determine the infestations of cows and buffaloes with some internal parasites with or without Fasciola in the same animal, and also determination of some bacterial causes of liver infection in the presence and absence of liver fluke. In vitro sensitivity of the isolated bacteria to different chemotherapeutic agents was also achieved. 


\section{Parasitological examination:}

- Examined animals:

A- Cows:

1-Faecal samples:

Samples were taken from 218 cows (sporadic cases aged between 8 months to 6 years), each individual animal sample in plastic bag, labeled and numbered for each animal and sent directly to Beni Suef laboratory of Animal Health Research for parasitological examination 2- Gall bladders:

Parts from livers beside the whole gall bladders of 43 feedlot beef and adult cows were collected from Beni Suef abattoir (18 of them were infested with Fasciola) in plastic bags, numbered for each animal and sent to Beni Suef laboratory of Animal Health Researches in an ice box for bacteriological examination

B- Buffaloes:

1-Faecal samples:

Samples were taken from 167 buffaloes aged between 1-7 years, each individual animal sample in plastic bag, labeled and numbered for each animal and sent directly to Beni Suef laboratory of Animal Health Researches for parasitological examination

2- Gall bladder

Parts from livers beside the whole gall bladder of 67 feedlot beef and adult buffaloes were collected from Beni Suef abattoir (34 of them were infested with Fasciola) in plastic bags, numbered for each animal and sent to Beni Suef laboratory of Animal Health Researches in an ice box for bacteriological examination.

\section{Method of parasitological examination:}

Faecal examination was carried out according to Welch et al. (1987) to detect Fasciola eggs. Concentration floatation technique was carried out according to Soulsby (1982) for detection of nematodes infected animals. Centrifugal sedimentation floatation technique for Eimeria was followed according to Yakhchalim and Cheraghi (2007).

\section{Bacteriological examination:- Samples: -}

Parts from livers of 67 buffaloes and 43 cows and the whole gall bladder of them were collected from abattoir of Beni Suef Governorate in plastic bags and transported directly to Beni Suef laboratory of Animal Health Researches in an ice box. 


\section{Media used for isolation:-}

-Blood agar medium.

-MacConkey agar medium (Oxoid).

-Tryptone soya agar medium (Biolife).

-Tryptone soya broth (Oxoid).

-Brain heart infusion broth (Biolife).

\section{Bacterial isolation and identification:-}

All samples were cultured onto different media in duplicated plates and incubated under aerobic and anaerobic conditions (in anaerobic jar containing $6 \%$ carbon dioxide) at $37^{\circ} \mathrm{C}$ for $24-72 \mathrm{~h}$ according to Cruick- Shank et al. (1975) and Collee et al. (1996). The isolated colonies were purified and identified morphologically and biochemically according to Tan et al. (1994) and Collee et al. (1996).

Serological typing of isolated $\boldsymbol{E}$. coli: -(according to Ewing, 1986).

Agar slants containing generous growth of the isolated strains of E. coli were submitted for agglutination test using polyvalent and monovalent O, E. coli antisera obtained from Denka Seiken Co., LTD. Japan Seiken Set 1 Code 312001

\section{Antimicrobial susceptibility: -}

1-For the isolates of aerobic bacteria: -

The disc diffusion technique was adopted according to Koneman et al. (1992). Antimicrobial discs and their inhibition zones were shown in Table (1)

2- For the isolates of Fusobacterium necrophorum and Actinomyces pyogenes:-

Minimum inhibitory concentration (MIC) to some antimicrobial food additives were determined in $U$ shape microtiter dilution plates according to Reddy et al., (1982) and Rosenblatt (1986). The plates were read visually (button in the bottom of the well) for growth. The MIC value was recorded as the lowest concentration of the antimicrobial compound that inhibited growth of the organism. 
Table 1: Interpretation of zones of inhibition for antimicrobial susceptibility according to manufacture company (BiomMerieux)

\begin{tabular}{|l|c|c|c|}
\hline \multirow{2}{*}{ Antimicrobial agent } & Concentration $\backslash \mu \mathrm{g}$ & \multicolumn{2}{|c|}{ Zone of inhibition (mm) } \\
\cline { 3 - 4 } & & Resistant $(\mathrm{R}) \leq$ & Sensitive $(\mathrm{s}) \geq$ \\
\hline Cefotaxin & 30 & 14 & 18 \\
\hline Rifamycin & 30 & 21 & 22 \\
\hline Gentamicin & 10 & 12 & 15 \\
\hline Ampicillin & 10 & 22 & 30 \\
\hline Streptomycin & 10 & 11 & 15 \\
\hline Oxytetracycline & 30 & 14 & 19 \\
\hline Ceftiofur & 30 & 19 & 23 \\
\hline Lincomycin + & 15 & 16 & 20 \\
\hline Spectinomycin & 200 & 12 & 18 \\
\hline Florfenicol & 30 & 14 & 16 \\
\hline Naldexic acid & 30 & & \\
\hline
\end{tabular}

\section{RESULTS}

\section{Parasitological examination:}

Faecal examination of 167 buffaloes and 218 cows as in Table (2) showed that 10, 16, 17 and 2 buffaloes had infestation with Fasciola, Paramphistomum, Gastro Intestinal Parasites and Coccidia spp. respectively with incidences of $5.99 \%, 9.58 \%, 10.18 \%$ and $1.20 \%$. While, 18, 24, 26 and 4 cows had infestation with Fasciola, Parmphistomum, Gastro Intestinal Parasites and Coccidia respectively with percentages of $8.26 \%, 11 \%, 11.93 \%$ and $1.83 \%$. Belonging to double infestation with Fasciola and other parasites as in Table (3) from 10 buffaloes 3(30\%) had Fasciola and Gastro Intestinal Parasites while 2 (20\%) had Fasciola and Paramphistomum. Regarding cows, 7 from 18 (38.89\%) were infested with both Fasciola and Paramphistomum species, while $5(27.78 \%)$ were found infested with both Fasciola and Gastro Intestinal Parasites. On the other hard coccidial infection was found in 2 non-infested buffaloes and 4 non infested cows with Fasciola. 
Table 2: Parasitic infestation (faecal examination).

\begin{tabular}{|c|c|c|c|c|}
\hline \multirow{2}{*}{ Parasites } & \multicolumn{2}{|c|}{ Buffalo } & \multicolumn{2}{c|}{ Cows } \\
\cline { 2 - 5 } & detsefnI & $\%$ & detsefnI & $\%$ \\
\hline aloicsaF & $10 / 167$ & $5.99 \%$ & $18 / 218$ & $8.26 \%$ \\
\hline mumotsihpmaraP & $16 / 167$ & $9.58 \%$ & $24 / 218$ & $11 \%$ \\
\hline $\begin{array}{c}\text { Gastro Intestinal Parasites } \\
\text { (G.I.P.) }\end{array}$ & $17 / 167$ & $10.18 \%$ & $26 / 218$ & $11.93 \%$ \\
\hline aidiccoC & $2 / 167$ & $1.20 \%$ & $4 / 218$ & $1.83 \%$ \\
\hline
\end{tabular}

Table 3: Mixed infestation with both Fasciola and other parasites.

\begin{tabular}{|c|c|c|c|c|}
\hline \multirow{2}{*}{ Parasites } & \multicolumn{2}{|c|}{ seolaffuB } & \multicolumn{2}{c|}{ swoC } \\
\cline { 2 - 5 } & detsefnI & $\%$ & detsefnI & $\%$ \\
\hline $\begin{array}{c}\text { htiw aloicsaF } \\
\text { mumotsihpmaraP }\end{array}$ & $2 / 10$ & $20 \%$ & $7 / 18$ & $38.89 \%$ \\
\hline htiw aloicsaF(G.I.P) & $3 / 10$ & $30 \%$ & $5 / 18$ & $27.78 \%$ \\
\hline latoT & $5 / 10$ & $50 \%$ & $12 / 18$ & $66 / 67 \%$ \\
\hline
\end{tabular}

\section{Fasciola ova}

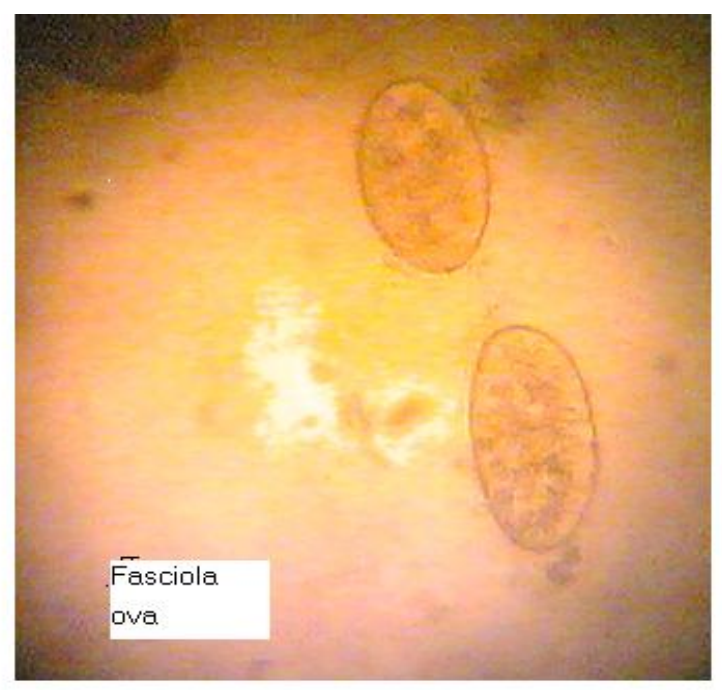

\section{Bacteriological examination}

Bacteriological examination of 110 gall bladder and parts of liver of buffaloes and cows revealed isolation of 97 isolates of bacteria from 88 positive samples as shown in Tables (4) \& (5) 
Table 4: Incidence of bacterial, Fasciola and mixed infection of liver and gall bladder of cows and buffaloes

\begin{tabular}{|c|c|c|c|c|c|c|c|c|c|c|c|}
\hline \multirow{2}{*}{ Species } & \multirow[t]{2}{*}{$\begin{array}{l}\text { No of } \\
\text { Examined } \\
\text { Animals }\end{array}$} & \multicolumn{2}{|c|}{$\begin{array}{l}\text { Bacterial } \\
\text { Infected } \\
\text { Animals }\end{array}$} & \multicolumn{2}{|c|}{$\begin{array}{l}\text { Fasciola } \\
\text { Infected } \\
\text { Animals }\end{array}$} & \multicolumn{2}{|c|}{$\begin{array}{l}\text { Mixed } \\
\text { Infected } \\
\text { Animals }\end{array}$} & \multicolumn{2}{|c|}{$\begin{array}{l}\text { Bacterial } \\
\text { infected animal } \\
\text { without } \\
\text { Fasciola }\end{array}$} & \multicolumn{2}{|c|}{$\begin{array}{l}\text { Fasciola } \\
\text { infected animal } \\
\text { without bacteria }\end{array}$} \\
\hline & & & & No & $\%$ & No & & No & $\%$ & No & $\%$ \\
\hline Cows & 43 & 38 & 88.37 & 18 & 41.86 & 18 & 41.86 & 20 & 46.51 & 0 & 0 \\
\hline Buffaloes & 67 & 50 & 74.63 & 34 & 50.75 & 31 & 46.27 & 19 & 28.36 & 3 & 4.48 \\
\hline Total & 110 & 88 & 80 & 52 & 47.27 & 49 & 44.55 & 39 & 35.46 & 3 & 2.73 \\
\hline
\end{tabular}

Table 5: Incidence of some bacterial isolates in infected livers of cows and buffaloes.

\begin{tabular}{|l|c|c|}
\hline \multicolumn{1}{|c|}{ Species } & No & $\%$ \\
\hline F. necrophorum & 13 & 13.40 \\
\hline E. coli & 12 & 12.37 \\
\hline Ser. Marcescens & 11 & 11.34 \\
\hline Ps. Aeruginosa & 10 & 10.31 \\
\hline Ent. Aerogenes & 9 & 9.28 \\
\hline A. pyogenes & 8 & 8.25 \\
\hline S. aureus & 7 & 7.21 \\
\hline Strept. uberis & 6 & 6.19 \\
\hline E. faecalis & 6 & 6.19 \\
\hline Pr. Valgaris & 6 & 6.19 \\
\hline E. faecium & 5 & 5.15 \\
\hline Pr. mirabilis & 4 & 4.12 \\
\hline \multicolumn{1}{|c|}{ Total } & 97 & 100.00 \\
\hline
\end{tabular}


Fig. 1: Frequent distribution of some bacterial isolates in infected livers of cows and buffaloes.

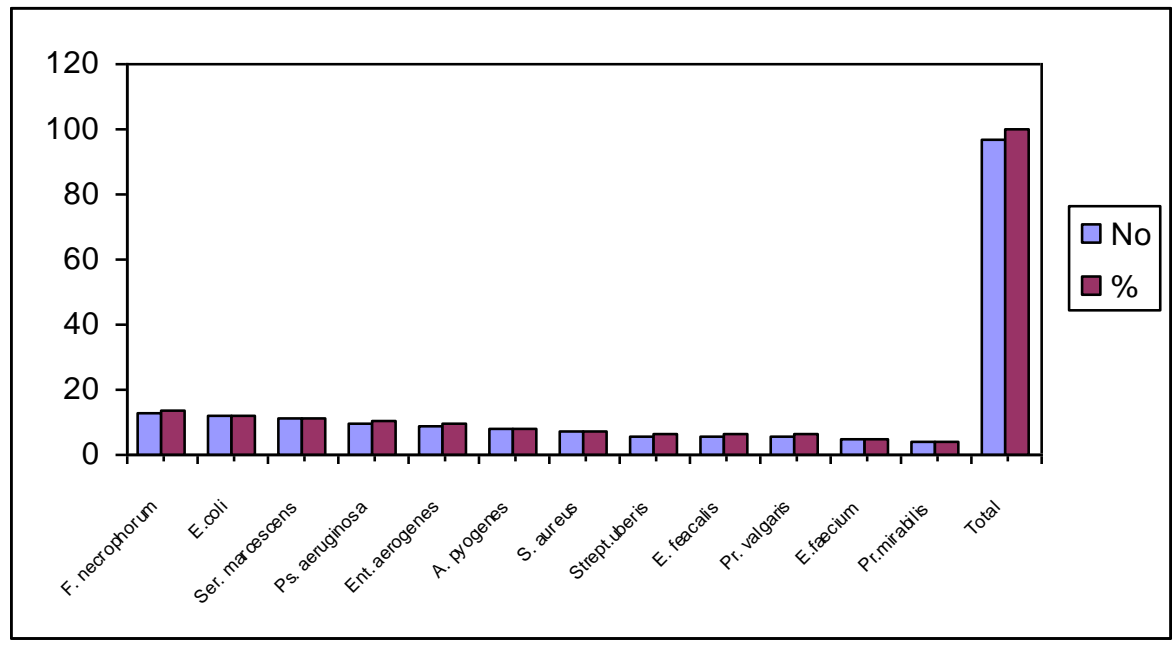

Table 6: Antimicrobial sensitivity of E. coli, S.aureus and Strept. uberis isolated from infected liver to different chemotherapeutic agents.

\begin{tabular}{|c|c|c|c|c|c|c|c|c|c|}
\hline \multirow{3}{*}{$\begin{array}{l}\text { Chemotherapeutic } \\
\text { Agents }\end{array}$} & \multicolumn{2}{|c|}{ E. coli $(12)$} & \multirow{3}{*}{$\begin{array}{l}\text { Chemotherapeutic } \\
\text { agents }\end{array}$} & \multicolumn{3}{|c|}{ S.aureus (7) } & \multicolumn{3}{|c|}{ Strept.uberis (6 } \\
\hline & \multirow[t]{2}{*}{$\mathrm{R}$} & $S$ & & \multirow[t]{2}{*}{$\mathrm{R}$} & \multicolumn{2}{|r|}{$S$} & \multirow[t]{2}{*}{$\mathrm{R}$} & \multicolumn{2}{|c|}{$S$} \\
\hline & & No $\%$ & & & No & $\%$ & & $\mathrm{~N}$ & $\%$ \\
\hline Ceftiofur & 0 & $12 \quad 100$ & Cefotaxin & 0 & 7 & 100 & 0 & 6 & 100 \\
\hline Gentamicin & 3 & 75 & Rifamycin & 0 & 7 & 100 & 0 & 6 & 100 \\
\hline $\begin{array}{l}\text { Lincospectin+ } \\
\text { Spectinomycin }\end{array}$ & 4 & $\begin{array}{ll}8 & 66.67 \\
\end{array}$ & Gentamicin & 3 & & 57.14 & 3 & 3 & 50 \\
\hline Naldexic acid & 7 & 41.65 & Ampicillin & 5 & 2 & 28.57 & 3 & 3 & 50 \\
\hline Florfenicol & 7 & 41.65 & Streptomycin & 7 & 0 & 0 & 4 & 2 & 33.33 \\
\hline Oxytetracycline & 8 & 33.33 & Oxytetracycline & 3 & 4 & 57.14 & 2 & 4 & 66.67 \\
\hline
\end{tabular}

Table 7: Minimum inhibitory concentration (MIC) for isolates of $F$. necrophorum and A. pyogenes to some antimicrobial food additives by $(\mu \mathrm{g} \backslash \mathrm{ml})$

\begin{tabular}{|l|c|c|}
\hline Antimicrobial food additives & F. necrophorum & A. pyogenes \\
\hline Tylosin & 8.9 & 5.5 \\
\hline Chlortetracycline & 2.5 & 1.5 \\
\hline Oxytetracycline & 3 & 1.2 \\
\hline
\end{tabular}




\section{DISCUSSION}

The parasitological and bacteriological examinations of cows and buffaloes, revealed that there were some parasitic and bacterial infections either single or mixed infections (Fasciola with bacteria or with other parasite in one animal). Faecal analysis of 218 cows indicated that, there were $8.26 \%, 11.93 \%, 11 \%$ and $1.83 \%$ cases infested with, Fasciola, Gastro Intestinal Parasites (G.I.P.), Paramphistomum and Coccidia spp. Respectively. As for buffaloes 5.99\%, 10.18\%, 9.58\% and $1.20 \%$ proved to be infested by Fasciola, Gastro Intestinal Parasites, Paramphistomum and Coccidia spp respectively. The higher rates of infestations with parasites in cows than buffaloes may be due to different numbers of examined animals, or other different factors as individual susceptability.

Belonging to the mixed infections, there were $66.67 \%$ of the fasciolised cows had faecal-borne parasites where $27.78 \%$ of the fasciolised cows were infested by Gastro Intestinal Parasites while $38.89 \%$ from the fasciolised cows were infested by Paramphistomum. These results agreed with those of Ogunrinade and Adegoke (1982) in Nigeria who reported that $61.9 \%$ had faecal-borne parasites and $85.8 \%$ had positive bacterial isolates in the bile in cows infested with Fasciola. In buffaloes there were 50\% had fecal-borne parasites, 30\% from the fasciolised buffaloes were infested by G.I.P. and $20 \%$ were infested by Paramphistomum. The rate of mixed infestations with both Fasciola and Gastro Intestinal Parasites was higher in buffaloes than in cows, but lower in mixed infestation with both Fasciola and Paramphistomum than in cows. These mixed infections may be due to cross resistance which has also been demonstrated between Schistosoma mansoni and $F$. hepatica, by Christensen, et al. (1980) cited by Ogunrinade (1982), also Goose (1977) as cited by Ogunrinade (1982), demonstrated a depression of immune responses in Fasciola hepatica in rat but at the same time a "non-specific immunostimulant" effect acts against trypanosomiasis in the same animals were noticed. Mixed infestations by coccidian and Fasciola were n't observed in this work may be due to low rates of coccidiosis detected (1.83\% in cows and $1.20 \%$ in buffaloes).

The bacteriological examination indicated that $80 \%$ of the examined samples as shown in Table (4) were positive, $44.55 \%$ of the examined samples were mixed with liver fluke infestations and $35.46 \%$ were pure bacterial infected samples. $2.73 \%$ of the examined samples contained liver fluke without bacterial infection this was due to some owners either used animicrobial food additives in the animal rations, the 
animals were administrated animicrobial agents before slaughter or their was no factor to cause bacterial infection at all. Different species of bacteria were detected in the examined samples (Table 5) either alone or in combination with coliform bacilli which were detected at different rates as follows: E. coli $12.37 \%$, Serratia. marcescens $11.34 \%$, Proteus spp. $10.31 \%$ and Ent.aerogenes $9.28 \%$. These results agreed with AbdelFattah et al. (1995) who isolated coliform bacilli from 26 samples of inflamed cattle livers, Nagaraja et al. (1999) could isolate E. coli, Proteus spp. and other facultative bacteria from $22 \%$ of liver samples with abscess, Reinsten et al. (2007) who isolated E. coli O157: H7from $0.54 \%$ of gall bladder of cattle and Matsumoto et al. (2008) who isolated coliform bacilli from 52 out of 232 bile samples of cattle. Staphylococcus and Streptococcus spp. were isolated from the infected livers at a rate of $7.21 \%$ and $6.19 \%$ respectively, similar results were recorded by Berg and Scanlan (1982) and Lechtenberg et al. (1988). Enterococcus and Pseudomonas species were isolated at a rate of $11.34 \%$ and $10.31 \%$ respectively, El-Dakhly et al. (2007) could isolate them from liver of cattle, sheep and camel at a rate of $25.92 \%$ and $3.70 \%$ respectively. $F$. necrophorum was detected in $13.40 \%$ of samples and this result agreed to some extent with Nagaraja et al. (1993) who isolated it from $100 \%$ of liver abscess. Abdel-Fattah et al. (1995) isolated $F$. necrophorum from 26 inflamed livers and 30 liver abscess of cattle. Eight isolates of $A$. pyogenes were isolated from inflamed livers and gall bladders $(8.25 \%)$, this result resemble the results recorded by Nagaraja et al. (1999) who isolated it from $10 \%$ of liver samples. However, high rate was recorded by Abdel-Fattah et al. (1995) who isolated it from 17 out of 26 inflamed liver samples of cattle.

Regarding to serological identification of 12 isolates of E.coli obtained from inflamed liver samples and gall bladders, the serogroups $\mathrm{O}$ were as follows O111 (4isolates) O29 (4isolates) O26 (3isolates) and O164 one isolate. Similar results were recorded by Blanco et al. (1993) who isolated E. coli O26 from cattle with diarrhoea, Orden et al. (1999) and Roopnarine et al. (2007) who isolated E. coli O111 and other serogroups from cattle and calves with diarrhoea.

Regarding to antimicrobial susceptibility, Table (6) indicating that all isolated E.coli strains were sensitive to ceftiofur, $75 \%$ to $66.67 \%$ of the tested strains were sensitive to gentamicin and lincospectin+ spectinomycin and moderately sensitive to florfenicol, naldexic acid and oxytetracycline. These results agreed with the results recorded by Ahmed et al. (1994), Bywater et al. (2004) and Checkley et al. (2008). All 
Staphylococcus and Streptococcus isolates were susceptible to cefotaxin and rifamycin, moderately resistant to gentamycin, ampicillin and oxytetracycline. Guerin et al. (2002) recorded that all Strept. ubris strains isolated from clinical mastitis were susceptible to chloramphenicol and rifampicin also similar results were recorded by Hendriksen et al. (2008) who reported that some Staphylococcus and Streptococcus isolated from cattle exhibited some resistant to gentamycin and tetracycline. Two isolates of Strept. ubris (33.33) were streptomycin sensitive and $66.66 \%$ of the isolates were resistant. This results are similar to the results recorded by Owens et al. (1990) who indicated that $62 \%$ out of 144 strains of Strept. ubris were resistant to streptomycin and Ebrahimi et al. (2008) who demonstrated that Strept. ubris isolated from mastitic milk showed high level of resistance against streptomycin.

In case of M.I.C of tylosin, chlortetracycline and oxytetracycline for $F$. necrophorum and A. pyogenes which were shown in Table (7), the results cleared that $F$. necrophorum isolates were susceptible to high concentrations of tylosin, chlortetracycline and oxytetracycline more than $A$. pyogenes isolates and this may be due to over use of these antimicrobial agents, these results nearly agreed with the results recorded by Lechtenberg and Nagaraja (1989), Nagaraja et al. (1993) and Tan et al. (1994).

In conclusion different species of bacteria were isolated from hyperemic and serotic livers samples and gall bladders of cattle, the occurrence of this bacteria either due to the aggressive grain feeding programs in feedlot animals which progress acidosis, rumenitis and consequently liver infection or due to the cirrhosis caused by liver fluke, which progress nephritis and liver infection or both causes coalesce together to produce liver infected with bacteria.

\section{REFERENCES}

Abdel-Fattah, A.M.; Saied, A.M. and Saied, Ash. M. (1995): Bacteriological assessment of inflamed cattle livers with special view to hepatic abscesses. Assiut Vet. Med. J. (32) 64: 96-101

Ahmed, I.; Yadava, J.N.S. and Ahmed, S. (1994): High level transferable resistance among E. coli. Ind. J. Anim. Sci. 64 (5) 439-445

Berg, J.N. and Scanlan, C.M. (1982): Studies of Fusobacterium necrophorum from bovine hepatic abscesses: Biotypes, quantitation, virulence, and antibiotic susceptibility. Am. J. Vet. Res. 43:1580 $\square 1586$ 
Blanco, M.; Blanco, J.; Blanco, J.E. and Ramos, J. (1993): Enterotoxigenic, verotoxigenic, and necrotoxigenic Escherichia coli isolated from cattle in Spain. Am. J. Vet. Res.; 54(9): 14461451.

Braun, U.; Jehle, W.; Thio, T. and Pospischil, A. (2004): Tenesmus in a cow with a liver abscess and nephritis [Case report] Dtsch Tierarztl Wochenschr. 111(1): 42-46

Brink, D.R.; Lowry, S.R.; Stock, R.A. and Parrott, J.C. (1990): Severity of liver abscesses and efficiency of feed utilization of feedlot cattle. J. Anim. Sci. 68:1201 $\square 1207$.

Bywater, R.; Deluyker, H.; Deroover, E.; de Jong, A.; Marion, H.; McConville, M.; Rowan, T.; Shryock, T.; Shuster, D.; Thomas, V.; Vallé, M. and Walters, J. (2004): A European survey of antimicrobial susceptibility among zoonotic and commensal bacteria isolated from food-producing animals. J. Antimicrob Chemother. 54(4): 744-754.

Checkley, S.L.; Campbell, J.R.; Chirino-Trejo, M.; Janzen, E.D. and McKinnon, J.J. (2008): Antimicrobial resistance in generic fecal Escherichia coil obtained from beef cattle on arrival at the feedlot and prior to slaughter, and associations with volume of total individual cattle antimicrobial treatments in one western Canadian feedlot. Can. J. Vet. Res.; 72(2): 101-108

Collee, J.G.; Fraser, A.Ca.; Marmion, B.P. and Simmons, A. (1996): Practical medical microbiology. $14^{\text {th }}$ Ed. Charchill Livingstone. Cruick-Shank, R.; Duguid, J.P.; Marion, B.P. and Swain, R.H.A. (1975): Medical Microbiology. $12^{\text {th }}$ ed., Vol. II. Churchill Livingstone, Edinburgh, London and New-York.

Ebrahimi, A.; Nikookhah, F.; Nikpour, S.; Majiian, F.; Gholami, M. (2008): Isolation of Streptococci from milk samples of normal, acute and subclinical mastitis cows and determination of their antibiotic susceptibility patterns. Pak. J. Biol. Sci. 1; 11(1): 148-50.

El-Dakhly, Kh. M.; Hassan, W.H. and Lotfy, H.S. (2007): Some parasitic and bacterial causes of liver affections in ruminants. Beni Suef. Vet. Med. J. Nove. $5^{\text {th }}$ Scient. Conf. 62-68

Ewing, W.H. (1986): Edward's and Ewings identification of enterobacteriaceae $4{ }^{\text {th }}$ Ed., Elsevier Science., New York. 
Guérin, F.V.; Tardy, F.; Bouveron, C. and Carret, G. (2002): Antimicrobial susceptibility of Streptococcus species isolated from clinical mastitis in dairy cows. Int. J. Antimicrob Agents. Mar; 19(3): 219-226.

Hendriksen, R.S.; Mevius, D.J.; Schroeter, A.; Teale, C.; Meunier, D.; Butaye, P.; Franco, A.; Utinane, A.; Amado, A.; Moreno, M.; Greko, C.; Stärk, K.; Berghold, C.; Myllyniemi, A.L.; Wasyl, D.; Sunde, M. and Aarestrup, F.M. (2008): Prevalence of antimicrobial resistance among bacterial pathogens isolated from cattle in different European countries: 2002-2004 Acta Vet. Scand 8; 50: 28.

Khan, W.I.; Blennerhasset, P.A. Varghese, A.K.; Chowdhury, S.K.; Omsted, P.; Deng, Y. and Collins, S.M. (2002): Intestinal nematode infection ameliorates experimental colitis in mice Infec. Immun. (70)11: 5931-5937.

Konman, E.W.; Allen, S.D.; Jan, W.M.; Schrechn, Berrjer, P.C. and Winn, T.R. (1992): Colour Atlas and Textbook of Diagnostic Microbiology $4^{\text {th }}$ ed. J. B. Lippicntt Co. Philadelphia U.S.A.

Lambertucci, J.R.; Rayes, A.A.; Serufo, J.C.; Nobre, V. (2001): Pyogenic abscesses and parasic diseases. Rev. Inst. Med. Trop Smo. Paulo. 43: 67-74.

Lambertucci, J.R.; Rayes, A.A.M.; Serufo, J.C.; Teixeira, D.M.; Gespacher-Lara. R.; Nascimento, E.; Brasileiro-Filho, L.G. and Silva, A.C. (1998): Visceral larva migrans and tropical pyomyositis: a case report. Rev Inst Med Trop Smo Paulo 40: 383-385.

Lambertucci, J.R.; Teixeira, R. and Navarro, M.M.M. (1990): Liver abscess and schistosomiasis. A new association. Rev Soc Bras Med Trop 23: 239

Lechtenberg, K.F.; Nagaraja, T.G. and Chengappa, M.M. (1998): Antimicrobial susceptibility of Fusobacterium necrophorum isolated from bovine hepatic abscesses in cattle. Am. J. Vet. Res. 59: 44 $\square 47$.

Lechtenberg, K.F. and Nagaraja, T.G. (1989): Antimicrobial sensitivity of Fusobacterium necrophorum isolates from bovine hepatic abscesses. J. Anim. Sci. 67(Suppl. 1): 544 (Abstr.).

Lechtenberg, K.F.; Nagaraja, T.G.; Leipold, H.W. and Chengappa, M. M. (1988): Bacteriologic and histologic studies of hepatic abscesses in cattle. Am. J. Vet. Res. 49: 58 $\square 62$ 
Matsumoto, N.; Taniwaki, T.; Kinuta, M. and Murase, T. (2008): Isolation of Campylobacter jejuni and coliform bacilli from bile and liver obtained from slaughter cattle in Western Japan. J. Food Prot. 71(6):1228-1231

Nagaraja, T.G.; Beharka, A.B.; Chengappa, M.M.; Carroll, L.H.; Raun, A.P.; Laudert, S.B. and Parrott J.C. (1999): Bacterial flora of liver abscesses in feedlot cattle fed tylosin or no tylosin. J. Anim. Sci. 77: 973-978.

Nagaraja, T.G. and Chengappa, M.M. (1998): Liver abscesses in feedlot cattle: A Review. J. Anim. Sci. 76: 287-298.

Nagaraja, T.G.; Beharka, A.B.; Chengappa, M.M.; Carroll, L.H. Raun, A.P.; Laudert, S.B. and Parrott, J.C. (1993): Bacterial flora of liver abscesses from feedlot cattle fed tylosin or no tylosin. J. Anim. Sci. 71(Suppl. 1):278 (Abstr.).

Ogunrinade, A. and Adegoke, G.O. (1982): Bovine fascioliasis in Nigeria-intercurrent parasitic and bacterial infections. Tropical Animal Health and Production, 14, 2: 121-125.

Orden, J.A.; Ruiz-Santa-Quiteria, J.A.; Cid, D.; García, S.; de la Fuente, $R$. (1999): Prevalence and characteristics of necrotoxigenic Escherichia coli (NTEC) strains isolated from diarrhoeic dairy calves. Vet. Mic.; 66(4): 265-273

Owens, W.E.; Watts, J.L.; Greene, B.B. and Ray, C.H. (1990): Minimum inhibitory concentrations and disk diffusion zone diameter for selected antibiotics against streptococci isolated from bovine intramammary infections. J. Dairy Sci.; 73(5): 1225-31

Pinilla, A.E.; Lopes, M.C.; Ricaurte, O.; Castilho, B.; Murcia, M.I.; Nicholls, R.S., Duque, S. and Orozco, L.C. (2001): Liver abscess caused by Ascaris lumbricoidis: a case report. Rev. Inst. Med. Trop Smo Paulo 43: 343-346.

Rayes, A.A.; Nobre, V.; Teixeira, D.M.; Serufo, J.R.; Filho, G.B., Antunes, C.M. and Lambertucci, J.R. (2000): Tropical pyomyositis and human toxocarasis: a clinical and experimental study. Am JTop Med Hyg 109: 422-425

Reddy, C.A.; Cornell, C.P. and Fraga, A.M. (1982): Transfer of Corynebacterium pyogenes (Glage) Eberson to the genus Actinomyces as Actinomyces pyogenes (Glage) comb. Nov. Int. J. Syst. Bacteriol. 32: 419 429.

Reinstein, S.; Fox, J.T.; Shi, X. and Nagaraja, T.G. (2007): Prevalence of Escherichia coli O157: H7 in gallbladders of beef cattle. Appl. Environ. Microbiol. 73(3):1002-1004. 
Rosenblatt, J.E. (1986): Antimicrobial susceptibility testing of anaerobes. In: V. Lorian (Edited by) Antibiotics in Laboratory Medicine. pp 159 $\square$ 180. Williams and Wilkins, Baltimore, MD. Roopnarine, R.R.; Ammons, D.; Rampersad, J. and Adesiyun, A.A. (2007): Occurrence and characterization of verocytotoxigenic Escherichia coli (VTEC) strains from dairy farms in Trinidad. Zoonoses Public Health.; 54(2): 78-85.

Silvia, I. Cazorla; Pablo D. Becker; Fernanda M. Frank; Thomas Ebensen; María J. Sartori; Ricardo S. Corral; Emilio L. Malchiodi and Carlos A. Guzmán (2008): Oral Vaccination with Salmonella enterica as a Cruzipain-DNA Delivery System Confers Protective Immunity against Trypanosoma cruzi. Infec. Imm., 76, 1, 324-333.

Soulsby, E.J.L. (1982): Helminths, Arthropods and Protozoa of Domesticated Animals, $7^{\text {th }}$ Ed. Bailliere, Tindall and Cassell LTD., London. P. 765

Tan, Z.L.; Nagaraja, T.G. and Chengappa, M.M. (1994): Biochemicaland biological characterization of ruminal Fusobacterium necrophorum. FEMS Microbiol. Lett. 120: $81 \square 86$.

Welch, S.; Malone, J. and Geghan, H. (1987): Herd evaluation of Fasciola hepatica infection in Louisiana cattle by ELISA Am. Vet. Res., 48 (3): 345-377.

Weng, M.; Huntley, D.; Huang, I.F.; Ondulla, F.J.; Lijian, W.; Aliese, S.; Qingping, Z.; Allan, W.; Bobby, J.C. and Hai Ning, S. (2007): Alternatively Activated Macrophages in Intestinal Helminth Infection: Effects on Concurrent Bacterial Colitis. The Journal of Immunology, 179: 4721-4731.

Yakhchalim, M. and Cheraghi, E. (2007): Eimeriosis in Bactrian and Dromedary camels in the Miandoab region, Iran Acta Vet. (Biogard) 57 No. 5-6: 545-62. 